\title{
Effects of fertilizer type and harvesting age on species composition, yield and chemical composition of natural pasture in the highlands of Ethiopia
}

\author{
SHIFERAW YALEW ${ }^{1}$, BIMREW ASMARE ${ }^{2, \boldsymbol{v}}$, YESHAMBEL MEKURIAW ${ }^{2}$ \\ ${ }^{1}$ North Mecha District Livestock Development Office. West Gojam Zone, Ethiopia \\ ${ }^{2}$ School of Animal Science and Veterinary Medicine, Bahir Dar University. P.O. Box 79, Bahir Dar, Ethiopia. \\ Tel: +251-583-209653, Fax: +251-583-20-60 94, `email: limasm2009@gmail.com
}

Manuscript received: 3 August 2020. Revision accepted: 5 October 2020.

\begin{abstract}
Yalew S, Asmare B, Mekuriaw Y. 2020. Effects of fertilizer type and harvesting age on species composition, yield, and chemical composition of natural pasture in the highlands of Ethiopia. Biodiversitas 21: 4999-5007. The experiment was conducted to evaluate the effects of fertilizer type and harvesting age on species composition, yield, and chemical composition of natural pasture in the highlands of Ethiopia. The experiment was laid out in randomized complete block design with factorial arrangement of two factors (fertilizer and harvesting age) with five replications. The data collected from the current study were forage species composition, dry matter yield, and chemical composition of natural pasture at different ages of harvesting. Forage species composition was determined by taking representative samples and identifying species from each sampling site. The samples of natural pasture were harvested at 90 and 120 days of age, weighed, dried, and then ground after that subsamples were taken for analyses of dry matter (DM), crude protein (CP), ash, acid detergent fiber (ADF), neutral detergent fiber (NDF) and acid detergent lignin (ADL). All the collected data were subjected to GLM ANOVA procedures of SAS version 9.0. The result indicated that all species composition and dry matter yield were significantly affected $(\mathrm{P}<0.001)$ by fertilizer type and harvesting ages. Higher forbs $(0.66 \%)$ were found in control plot at 90 days of harvesting age. Natural pasture harvested at 120 days of harvesting and urea fertilizer application results the highest dry matter yield (DMY) (8.26 t/ha) while the lowest level $(3.20 \mathrm{t} / \mathrm{ha})$ from unfertilized plot at 90 and 120 days of harvesting. The relative proportion of legumes in the natural pasture attained its climax stage at 90 days while grass attained at 120 days of harvesting. The highest mean DMY (6.24 tone/ha) was obtained at 120 days of harvesting and the lowest (4.71 ton/ha) at 90 days of harvesting. Among the chemical composition parameters, DM, ash and CP were significantly affected $(\mathrm{P}<0.001)$ by both fertilizer type and harvesting age. The content of $\mathrm{CP}$ and ash were increased with manure fertilizer at early harvest age and were decreased with delayed harvest age. The application of fertilizer type did not significantly affect $(\mathrm{P}>0.05)$ NDF content of the natural pasture rather affected by stage of harvesting $(\mathrm{P}<0.001)$. Regardless of DM yield, better quality pasture was recorded for early (90 days) harvesting age and use of compost recommended for future natural pasture improvements as use of chemical fertilizer is relatively expensive for the majority of smallholder farmers in the highlands.
\end{abstract}

Keywords: Fertilization, feed quality, grazing land, highlands of Ethiopia

\section{INTRODUCTION}

Though Ethiopia endowed with large livestock population (CSA 2018), the contribution of the livestock sub-sector is far below as compared to its potential. Even it is not possible to match demand and supply of animal products for domestic consumption (meat and milk). It is surprising that the country is importing dairy products from abroad with a high hard currency exchange to fill the demand gap (Tegegne et al. 2013). The reason why the country could not be self-sufficient in animal products is due to poor productivity of livestock because of many constraints. Shortage of quality and quantity of livestock feed in the country is taking the lion share for the poor livestock productivity (Mengistu et al. 2017). The major feed resources in the country are natural grazing land and crop residues (CSA 2017). In the country, grazing land resources contain approximately $25 \%$ of the total area coverage that supplies nearly $60 \%$ of total feed for ruminant livestock.
However, in most parts of Ethiopia the productivity was extremely low (Ulfina et al. 2013). This is mainly the result of erratic rainfall patterns, appropriate grazing management, change of existing pasture land to cultivatable farmland, caused by human population increment (Yadessa et al. 2016). Soil fertility status of the grazing lands is one of the main factors that could contribute to the low productivity, quality, and botanical composition of a natural pasture (Kebede et al. 2016; Głowacz and Niżnikowski 2018). As reported by Angassa (2014), heavy grazing pressure may reduce plant species composition as the result of erosion and compaction of soil. However, grazing land protection measures such as grazing excursion and controlled grazing could help to rehabilitate such degraded grazing lands (Mekuria et al. 2018). Generally, there was a severe shrinking of grazing resources together with marked decline in the quality and productivity of the natural pasture in the highlands of the country (Birhan and Adugna 2014). This problem inevitably calls for improving the productivity of the 
grazing lands in the country through appropriate management interventions.

There was only limited information on effect of fertilizer type and harvesting age on species composition, yield, and chemical composition in the highlands of Ethiopia which could be used as a strategy for increasing natural pasture productivity (Abadi 2017; Tesfay 2017). In addition, the mineral fertilizer price is increasing from year to year. Resource-poor farmers may not afford to purchase the desired amount for an optimal application (Ketema and Siegfried 2011). However, organic fertilizer application, understanding the harvesting age of the forage plants growing on the natural pasture could be promising for sustainable manner in the natural pasture improvement strategy in the tropics. The general goal of this study was to investigate effects of fertilizer application and age of harvesting and on grazing land and generate information that will provide insights as to future plans to improve yield and quality of natural pasture in the highlands of Ethiopia. Therefore, the main purpose of this study was to determine the better type of effect of fertilization and harvesting age on yield, species composition, and chemical composition of the natural pasture in Northwestern Ethiopia.

\section{MATERIALS AND METHODS}

\section{Description of the study area}

The study was conducted in North Mecha District, West Gojam Zone, Amhara National Regional State, Ethiopia. The area is located about $524 \mathrm{~km}$ north-west of Addis Ababa and about $40 \mathrm{~km}$ south of Bahir Dar town. It is situated at an altitude ranging from $1800-2500 \mathrm{~m}$ a.s.l. The area receives annual rainfall that ranges from about 820 to $2000 \mathrm{~mm}$ (MDOA 2019). The minimum and maximum daily temperatures of the area are $17^{\circ} \mathrm{C}$ and $30^{\circ} \mathrm{C}$, respectively. The major crops grown in the area are wheat, barley, millet, teff, and maize (DOA 2000). Based on the (CSA 2017) this district has a total population of 292,080 of whom 147,611 are men and 144,469 women; 22,677 or $7.76 \%$ are urban inhabitants, whereas the livestock populations were accounted as bovine, 351,844, from these 2377 crossbreed, ovine, 110,834, caprine, 61,883, equine, 39,214 and poultry, 230,286 from these 4494 crossbreeds (DOA 2019). A total of 66,107 households were counted in this district.

The district has a total area of 112,438 ha of which the actual cultivated land is 49,437 ha and the grazing land, forest, and bushland becomes 12,818.98, 21,245.6 ha, respectively, and 4,120.6 ha were used for construction. The landscapes of the district are flat, mountain and gorge which accounts 96, 2 and 2\%, respectively. Soil type $97 \%$ red and $3 \%$ brown and annual average temperature are $24^{\circ} \mathrm{C}$ (CSA 2018). The study was carried out in Ambomesk Keble, located at $11^{\circ} 22$ ' $58 \mathrm{~N}, 37^{\circ} 3^{\prime}$ ' 38 E latitude and longitude, respectively.

\section{Experimental site selection}

Prior to the start of this study, in most parts of the natural grazing area, the visual observation was conducted. Then, based on uniform ground cover, a representative natural pasture land was selected and fenced for the study purpose.

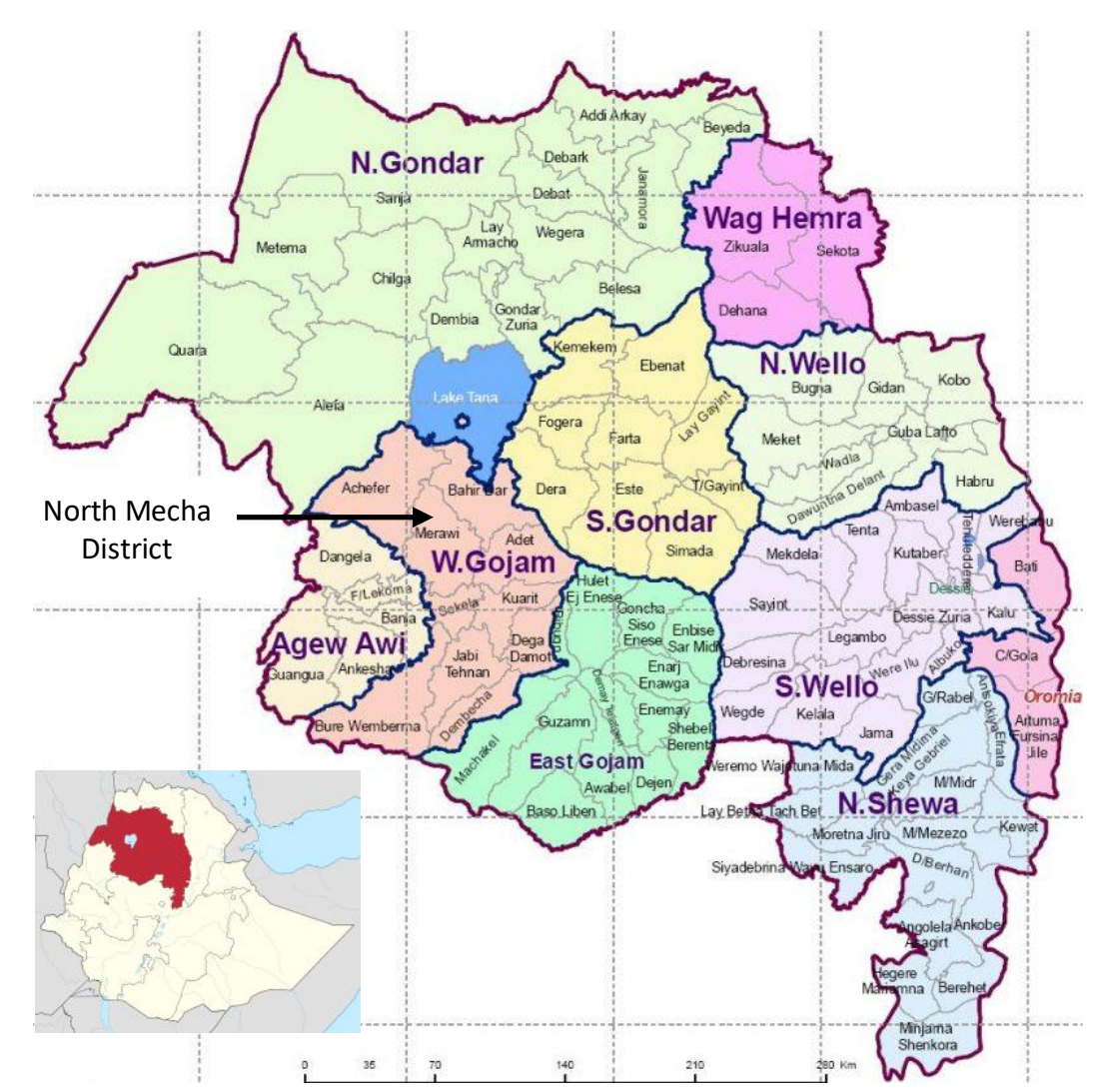

Figure 1. Map of the study area in North Mecha District, West Gojam, Amhara, Ethiopia 


\section{Treatments and experimental design}

The experiment had a total of eight treatment combinations consisting of four fertilizer type and two harvesting age arranged in a factorial randomized complete block design with five replications. The treatments used in this study were four fertilizer types (Urea, compost, mixture of urea and manure, and without fertilizer at 90 and 120 days of harvesting age. $100 \mathrm{~kg}$ urea fertilizer, $7.5 \mathrm{t}$ compost, and $50 \mathrm{~kg}$ urea and $3.75 \mathrm{t} \mathrm{ha}^{-1}$ for mixture of urea and compost were used for this study (Melese et al. 2016). The spacing between block and plots was $1 \mathrm{~m}$. There were five blocks, each containing eight plots resulting in forty plots in total with each plot measuring $2 \mathrm{~m} \times 3 \mathrm{~m}$. Total area of the experiment was $525 \mathrm{~m}^{2}(25 \mathrm{~m} \times 21 \mathrm{~m})$ and the natural pasture was fenced for the collection of current data.

\section{Data collection}

\section{Botanical composition}

The data on botanical composition of the natural pasture was carried out by harvesting randomly selected samples $(1 \mathrm{~m} \times 1 \mathrm{~m}$ quadrate $)$ which were randomly thrown three times per plot within each plot using a hand-operated sickle, at height of $5 \mathrm{~cm}$ above the ground at 90 and 120 days of harvesting Total fresh mass of the natural pasture was taken immediately after harvesting using measuring balance, following this, the species compositions were classified from samples of pasture in each experimental plot by counting (Mannetje et al. 1976). Identification of species was undertaken in the field together with experienced personnel on the basis of plant morphological, structural, and floristic characteristics of each botanical composition.

\section{Forage dry matter yield}

Quadrant method $(1 \mathrm{~m} \times 1 \mathrm{~m})$ was employed for the forage dry matter yield determination. The biomass was harvested using manual system by using sickle and by air drying a representative sample $(1 \mathrm{~kg})$ from an area of $(1 \mathrm{~m} \times$ $1 \mathrm{~m})$ until constant weight is achieved, followed by weighing using sensitive balance which was determined at each harvesting age. Then DM yield of each botanical component weighted all measurements to obtain total DM per plot where the final DM yield per hectare of land was reported. To determine the total dry matter weight, total fresh weight of plot divided by sub-sample fresh weight and multiplied by sub sample dry weight, following the method described by Tothill et al. (1978).

\section{Chemical analyses}

Samples at each harvesting ages were subjected to chemical analysis for determination of the forage chemical composition measurements such as crude protein $(\mathrm{CP})$ by Kjeldahl procedure (AOAC 2004), acid detergent fiber (ADF), neutral detergent fiber (NDF), and acid detergent lignin (ADL) were analyzed using According to Van Soest et al. (1991). Ash was determined by igniting the sample at $550^{\circ} \mathrm{C}$ overnight, total $\mathrm{DM}$ by drying at $105^{\circ} \mathrm{C}$. The dried samples were ground to pass through a $1-\mathrm{mm}$ sieve, and then stored individually in airtight containers for chemical analyses.

\section{Data analysis}

The botanical composition, DM yield, and chemical composition parameters were subjected to analyses of variance (ANOVA) using Generalized Linear Model (GLM) procedures of SAS statistical computer package version 9.0 (SAS 2004) and descriptive statistical analysis was also employed for percentages of the different species. Pearson correlation analysis was also performed to determine the association between botanical composition, forage yield, and nutritional parameters of the natural pasture. Mean separation was done for treatments shown significant using the least significant difference (LSD) at 5 $\%$ probability. The following mathematical model was applied to analyze the effect of all possible factors:

$$
Y i j=\mu+\mathrm{Fi}+\mathrm{Hj}+\mathrm{Fi} * \mathrm{Hj}+\mathrm{eij}
$$

Where,

Yij : Total observations

$\mu \quad$ : overall mean

$\mathrm{Fi}$ : effect of fertilizer type (urea, compost, mix, and control)

$\mathrm{Hj}$ : effect of harvesting age (at 90 and 120 days)

$\mathrm{F}_{\mathrm{i}}^{*} \mathrm{Hj}$ : the interaction of Fertilizer type and harvesting age

Eij : the error mean

\section{RESULTS AND DISCUSSION}

\section{Forage species identified from the natural pasture}

A total of seven herbaceous species were identified in this research, of which five were grasses, one legume, and one other herbage (forbs). Among the grass species were: Setaria pallidefusca, Eleusine floccifolia, Cynodon dactylon, Panicum coloratum, and Pennisetum macro rum. The legumes and forbs were Trifolium decorum species and Cyperus barbata respectively.

\section{Effect of fertilizer type and harvesting age on botanical composition and forage yield of natural pasture}

The interaction of fertilizer type and harvesting age on species composition (grass, legumes, and forbs) and forage yield are presented in Table 1 .

There were significant interactions between the effects of fertilizer type and harvesting age. The highest proportion $(82.17 \%)$ of grass was recorded with urea fertilizer application at 120 harvesting days, while the lowest $(16.73 \%)$ at compost application at 90 days of harvesting. Similarly the highest proportion $(82.9 \%$ of legumes were observed at compost at 90 days of harvesting age, while the lowest $(17.58 \%)$ was from urea fertilizer at 120 days of harvesting. The highest $(0.67 \%)$ and lowest $(0.26 \%)$ proportion of forbs were recorded in control group, urea, and mix treatment groups respectively. On the other hand, significantly higher forage yield $(8.27 \mathrm{t} / \mathrm{ha})$ was recorded at urea fertilizer application at 120 days of harvesting, while the lowest dry matter yield (3.2 t/ha) was from control group at both harvesting ages. 
Table 1. Effect of fertilizing type and harvesting age on share of functional groups and dry matter yield

\begin{tabular}{llllll}
\hline \multicolumn{2}{c}{ Variables } & \multicolumn{4}{c}{$\begin{array}{c}\text { Botanical composition (\%) and forage } \\
\text { yield (t/ha) }\end{array}$} \\
\hline HD & FT & Grass & Legumes & Forbs & DMY \\
\hline 90 & Compost & $16.73 \mathrm{c}$ & $82.9 \mathrm{a}$ & $0.36 \mathrm{c}$ & $4.14 \mathrm{c}$ \\
& Urea & $69.36 \mathrm{a}$ & $30.16 \mathrm{~d}$ & $0.48 \mathrm{~b}$ & $6.33 \mathrm{a}$ \\
& Mix & $43.50 \mathrm{~b}$ & $56.12 \mathrm{~b}$ & $0.37 \mathrm{c}$ & $5.17 \mathrm{~b}$ \\
& Control & $49.33 \mathrm{~d}$ & $49.33 \mathrm{c}$ & $0.67 \mathrm{a}$ & $3.2 \mathrm{~d}$ \\
& & & & & \\
120 & Compost & $26.68 \mathrm{~d}$ & $72.96 \mathrm{a}$ & $0.36 \mathrm{~b}$ & $6.33 \mathrm{c}$ \\
& Urea & $82.17 \mathrm{a}$ & $17.58 \mathrm{c}$ & $0.26 \mathrm{~d}$ & $8.27 \mathrm{a}$ \\
& Mix & $57.47 \mathrm{c}$ & $42.23 \mathrm{~b}$ & $0.29 \mathrm{c}$ & $7.09 \mathrm{~b}$ \\
& Control & $71.07 \mathrm{~b}$ & $28.49 \mathrm{c}$ & $0.42 \mathrm{a}$ & $3.29 \mathrm{~d}$ \\
Mean & & & & & \\
SEM & & 52.12 & 47.17 & 0.4 & 5.48 \\
CV & & 0.092 & 0.09 & 0.0021 & 0.078 \\
SL & & 0.58 & 0.63 & 11.58 & 1.61 \\
\hline
\end{tabular}

Note: HD: Harvesting date, FT: Fertilizer type, DMY: Dry matter yield, SEM: Standard error of mean, CV: Coefficient of variation, SL: Significance level, $\mathrm{p}^{* * *}$ : significant difference at p: 0.001

The species identified in the current finding were less than those reported by Zewdu et al. (2010) and Kebede et al. (2016) in different parts of Ethiopia. The discrepancy of current findings from those authors might be due to overgrazing and degradation of the grazing lands, environmental variations, management level of the natural pasture. However, most forage species identified in this study had similarities with previous reports of forage species in Ethiopia (Zewdu et al. 2010; Nemera et al. 2017).

\section{Effect of fertilizer type and harvesting age on grass proportion of natural pasture}

The interaction between type of fertilizer and harvesting age had significant $(\mathrm{P}<0.001)$ effect on the composition of grass (Table 2). The result showed that the highest proportions $(82.17 \%)$ of grasses were recorded at urea fertilizer at 120 harvesting days. Therefore, the application of nitrogen fertilizer had a higher grass botanical composition $(69.36 \%)$ as compared to application of compost $(16.73 \%)$, combined treatment $(43.50 \%)$, and control $(49.33 \%)$ at 90 days of harvesting. In the current study, however, there was an increment of grasses observed.

The result showed that the highest proportions of grasses were recorded at urea fertilizer at 120 harvesting days. This was due to the nitrogen contained in the urea fertilizer, able to cause the legume to be less competitive and be crowded out by the grasses in the pasture (Atsbha et al. 2015; Nemera 2016). According to Lloyd and Ritchey (2014), the chemical fertilizer gives immediate response for grasses due to release of nitrogen which enhanced the growth of grass species over legumes and critical for legumes establishment. The same result reported by Stephen (2013), showed that chemical fertilizer increased the grass contents because of more intensive and fast growth of grasses. Similarly, (Hanife et al. 2010), also noted that in studies of two years chemical fertilizer reduced the legume content and increased grass content and total dry matter yields.

Therefore, the application of nitrogen fertilizer had a higher grass botanical composition (as compared to application of compost, combined treatment and control $(49.33 \%)$ at 90 days of harvesting The finding shows that nitrogen fertilizer has important role in increasing the grass-legume mixture of the grazing lands (Numan et al. 2018). Increment in grass proportion through application of inorganic fertilizer is related to the faster dilution of nutrients in the fertilizer than the organic fertilizer in the soil system that has boosted the growth and development of grass components over legume, since grass were highly responding to nitrogen fertilizer (Bumane 2010). In the current study, unlike a decrease in the proportion of legumes, the proportion of grasses increased and such an increasing trend in the grass composition had also been reported on natural pastures studies in northwestern Ethiopia (Zewdu et al. 2010). The higher botanical composition of grasses than other forage species might be related to decreasing proportions of legumes in the pasture as a result of a suppression suffered from shading of grasses (Feyter et al. 2005).

\section{Effect of fertilizer type and harvesting age on legumes proportion of natural pasture}

The results showed that the legume botanical composition of natural pasture was highly influenced by urea fertilizer application and age of harvesting (Table 2). The effect of fertilizer type and age of harvesting had higher significance on legumes proportion $(\mathrm{P}<0.001)$.

The compost fertilizer increased the legume botanical composition with $(82.9 \%, 72.9 \%)$ at 90 and 120 days of harvesting, respectively compared to nitrogen fertilizer application $(30.16 \%, 17.57 \%)$, combined (56.12\%, $42.23 \%)$, and control $(49.33 \%, 28.49 \%)$ at 90 and 120 days respectively. The lower legumes recorded in nitrogen fertilizer plot $(17.57 \%)$ at 120 days. The combined treatment (nitrogen + compost) higher than the nitrogen fertilizer and control treatment in legumes component at 90 and 120 days of harvest. Legume proportion reached its maximum at 90 days of harvesting but decreased at 120 days of harvest.

In the current study compost fertilizer increased the legume species composition as compared to nitrogen fertilizer application, combined and control at 90 and 120 days, this in turn might be related to bioavailability of phosphorous that enhances development of legumes leading to the reduction in the inhibition effect on grass growth (Marie et al. 2014). Legume proportion reached its maximum at 90 days of harvesting but decreased at 120 days of harvest.

The majority of legumes, due to their short life span, defoliate at early age as compared to the grass species. This finding was in agreement with earlier reports of Zewdu et al. (2010) from northwestern Ethiopia. Thus, as observed, the annual legumes matured faster than grasses, aged, and gave way to the dominance of the perennial grasses. 


\section{Effect of fertilizer type and harvesting age on forbs proportion of natural pasture}

The effect of fertilizer and ages of harvesting was significant for forbs $(\mathrm{P}<0.001$ (Table 2). Higher proportion forbs $0.67 \%$ and $0.41 \%$ were found in control treatment group at 90 and 120 days of harvest respectively. Lower proportion of forbs were obtained from nitrogen fertilizer $(0.26 \%)$ and combined (nitrogen + compost) $(0.29 \%)$ from the second harvesting age (120 days) and they were statically not different. The results showed that no significant difference among the combined treatment (nitrogen + compost) and compost fertilizer, urea, and mix at 90 and 120 days of harvesting age respectively in terms of forbs proportion. On the other hand, harvesting age on compost fertilizer had no significant effect on the forbs proportion of the pasture in the current result.

Effe The reason why control treatments were higher in forbs was associated with the faster growth of annual weeds characters for competition of soil nutrients over others as reported by Zewdu et al. (2010). The current result is in line with Nemera (2016) reported that the control plots showed large proportion of forbs components and other unwanted plants which might be related to quick growth and development of annual weeds that in turn are pioneer plant communities in degraded ecosystems. The forbs proportion reached the highest at 90 days of harvesting and lowest at 120 days of harvesting; this result contradicts with (Denekew et al. 2005) who stated that forbs proportion increased with increasing stages of harvesting of natural pasture.

\section{Effect of fertilizer type and harvesting age on dry matter yield of natural pasture}

The dry matter yield of natural pasture was significantly affected $(\mathrm{p}<0.001)$ by the interaction effect of fertilizer type and harvesting age (Table 2). The highest DMY yield $(8.26 \mathrm{t} / \mathrm{ha})$ was produced on urea fertilizer at 120 days while the lowest dry matter yield was recorded from control groups $(3.20,3.29 \mathrm{t} / \mathrm{ha})$ at 90 and 120 days respectively. The effect of combined treatment had shown intermediate value between nitrogen and compost fertilizer at 90 and 120 days of harvesting. Therefore, all treatments except the control had positive significant effect on natural pasture yield obtained from 90 days of harvest and 120 days. Generally, the DMY ranged from 4.14 to $6.3 \mathrm{t} / \mathrm{ha}$, 6.34 to $8.26,5.17$ to 7.09 t/ha, on compost treatment, nitrogen fertilizer and mix at 90 and 120 days, respectively. While unfertilized treatment had no significant difference at 90 and 120 days of harvesting on dry matter yield of the natural pasture. The highest dry matter yield (8.26 t/ha) was found in nitrogen fertilizer at 120 days of harvesting while the lowest was from unfertilized treatment (3.20, $3.29 \mathrm{t} / \mathrm{ha})$ at 90 and 120 days of harvesting age respectively.

Similar studies conducted in Turkey by Ahmed et al. (2013) showed that yield of the grazing lands is the result of inorganic fertilizer addition. Cahit et al. (2010) showed that it is possible to boost forage yield and quality through addition of nitrogen and phosphorous. The highest total dry matter yield recorded by urea was associated with urea fertilizer which mineralizes quickly to release nitrogen which fastens the growth of high proportion of grass species. The study was also in agreement with Zewdu et al. (2010) stated that DM yields of the grass component increased with the application of nitrogen fertilizer in the north-western parts of Ethiopia. Even though chemical fertilizer increased the dry matter yield, in the current study it was lower (5.48 t/ha) than it was reported (11.33 t/ha) by Kebede et al. (2016) around Holeta, central highland of Ethiopia. This might be due to the nature of the soil, climatic factors (rainfall), and severity grazing land degradation prior to fertilizer application. The total mean DMY (6.29 t/ha) was higher than the present study $(5.48$ t/ha), which might be due to the late harvesting (170 days) as compared to our study (120 days), soil fertility, climatic factors and species composition of the pasture which were major factors that influence forage dry matter yield. The increase in DMY of natural pasture with advancing maturity agrees with other studies in different parts of Ethiopia (Agza et al. 2013; Nega et al. 2015) and it was the result of addition of tillers, leaf elongation, and stem development (David et al. 2019). The current study confirms that application of the different types of fertilizer could have potential to improve productivity of natural pasture; hence this can help to overcome shortage of feeds in the study area.

\section{Effect of fertilizer type and harvesting age on chemical composition of natural pasture}

The interaction effects among fertilizer type and harvesting age on the chemical composition of natural pasture is presented in (Table 2).

Significant interactions between the effect of fertilizer type and harvesting age on chemical composition of natural pasture were observed in the current study.

\section{Dry matter content}

In the current finding, dry matter content (DM \%) of the natural pasture influenced $(\mathrm{P}<0.001)$ by fertilizer type and harvesting stage. The highest value of dry matter content was recorded by nitrogen fertilizer application $(92.55 \%)$ at 120 days while the lowest value of dry matter content was recorded in compost $(90.30 \%)$, mix (91.21 and control $(90.35 \%)$ treatments at 90 days and the lowest groups were not showed significant different each other. On the other hand at 120 days of harvesting age except for nitrogen fertilizer, the organic $(91.21 \%)$, combined (nitrogen + compost) $(91.30 \%)$, and the control treatments $(91.20 \%)$ were statistically similar $(\mathrm{P}>0.05)$ in dry matter content.

The highest value of dry matter content was recorded by nitrogen fertilizer application at 120 days while the lowest value of dry matter content was recorded in compost, mix, and control treatments at 90 days. The results of current study were in line with reports in Ethiopia (Bumane 2010; Nemera 2016) in different parts of the country. These authors reported that application of nitrogen fertilizer increased natural pasture dry matter content. This was due to grass vigorously responded to nitrogen fertilizer application and showed that content increases with increasing harvesting age. This indicates that the water 
content of plants in the pasture decreases as in advancing growth. Similarly, an increase in DM content with increasing maturity in the current study was in agreement with the finding of (Rambau et al. 2016) who showed that the DM content increased as the grass matured. In the present study, the DM content increased as the age matured, and higher DM was observed at the late age of maturity. The current result was in agreement with Tolcha (2017) who suggested, dry matter content increased with delayed harvesting which could be attributed to decreased moisture content in leaves as plants age and become lignified. According to Gomide et al. (1969), the dry matter content of tropical grass increased linearly with an advance in age of the forage. This can be explained by the fact that an increase in structural components (cell walls) and a decline in the ratio of leaves to stems. The DM production potential of the grass in the present study was similar to those reported by (Nemera 2016) for natural pasture in Ethiopia (92.02\%). This might indicate tropical grass had similar dry matter percentage.

\section{Ash content}

The ash content observed in the current study varied both in fertilizer type and harvesting age at $(\mathrm{p}<0.001)$. The highest ash content was observed in compost fertilizer $(7.69 \%)$ followed by in combined treatment (nitrogen + compost) $(7.61 \%)$ at 90 days of harvesting and the lower result was observed in unfertilized plot $(5.43 \%)$ at 120 days harvesting. While nitrogen fertilizer was intermediate between compost and combined treatment at 90 days and between combined and control at 120 days of harvesting.

Higher ash content of natural pasture in compost was due to high mineral contents inherited from the manure fertilizer (Nemera 2016). The current findings also in agreement with Nemera et al. (2018) stated that application of cattle manure in natural pasture exhibited higher ash due to the fact that cattle manure is rich in phosphorous, potassium, magnesium, and calcium. Moreover, based on Aregheore (2002), the higher number of legumes present in compost fertilizer tends to accumulate more total macroand microminerals than grasses. The mean ash content $(6.83 \%)$ for natural pasture in the current study was different from Feyissa et al. (2014) in Ethiopia. Across all forage species, the major factors that impact forage mineral composition include fertilizer application, stage of growth, and environmental conditions (Mirzaei 2012). The current finding indicated that there was a decrease in total ash content of the natural pasture in late maturity. The result was in agreement with the one reported by Nega et al. (2015), a study conducted on natural pasture in Ethiopia. According to Maynard et al. (1981), at the late stage of plant growth, it is expected that there will be mineral nutrient dilution and assimilation in different vegetative parts of the plants. Halgerson et al. (2004) also reported that concentrations of most minerals were higher in leaves than in stems therefore, reduction in leaves at eight weeks caused the decline in potassium levels.

\section{Crude protein}

Fertilizer type and harvesting age had significant $(\mathrm{P}<0.001)$ effect on crude protein content of the natural pasture. Application of compost fertilizer resulted in the highest CP content of $(15.13 \%)$ at 90 days of harvesting, while the lowest CP $(7.23 \%)$ content was observed in the control plot from the late harvesting age (120 days). The nitrogen fertilizer $(8.81 \%)$ was lower than compost $(15.13 \%)$, combined treatment (nitrogen + compost) $(12.06 \%)$ and the control $(9.04 \%)$ at 90 days (Table 3). At 120 days of harvesting, the difference in CP content of forage harvested from compost applied treatment $(9.24 \%)$ and nitrogen + compost $(9.25 \%)$ applied treatment is not statistically different. The higher CP content from the compost plots could be explained by the density of legume components in the pasture which was higher than other treatments including the Nitrogen fertilizer. The crude protein content of the natural pasture has declined as age of harvesting increased.

Table 2. Effect between harvesting age and fertilizer type on the chemical composition of the natural pasture

\begin{tabular}{|c|c|c|c|c|c|c|c|}
\hline \multicolumn{2}{|c|}{ Variable } & \multicolumn{5}{|c|}{ Chemical composition parameter } & \multirow[b]{2}{*}{ ADL } \\
\hline HD & FT & DM & Ash & $\mathbf{C P}$ & NDF & ADF & \\
\hline \multirow[t]{4}{*}{90} & Compost & $90.30^{c}$ & $7.69^{\mathrm{a}}$ & $15.13^{\mathrm{a}}$ & 67.17 & $50.06^{\mathrm{b}}$ & $9.46^{\mathrm{a}}$ \\
\hline & Urea & $91.20^{\mathrm{b}}$ & $6.67^{\mathrm{c}}$ & $8.81^{\mathrm{c}}$ & 68.19 & $49.91^{\mathrm{b}}$ & $7.88^{\mathrm{b}}$ \\
\hline & $\operatorname{Mix}$ & $90.21^{\mathrm{c}}$ & $7.61^{\mathrm{b}}$ & $12.06^{\mathrm{b}}$ & 68.20 & $49.84^{\mathrm{b}}$ & $9.45^{\mathrm{a}}$ \\
\hline & Control & $90.35^{\mathrm{c}}$ & $6.52^{\mathrm{c}}$ & $9.04^{\mathrm{c}}$ & 68.16 & $51.38 \mathrm{c}^{\mathrm{a}}$ & $9.46^{\mathrm{a}}$ \\
\hline \multirow[t]{4}{*}{120} & Compost & $91.21^{\mathrm{b}}$ & $7.61^{\mathrm{a}}$ & $9.24^{\mathrm{a}}$ & 71.27 & $53.16^{\mathrm{b}}$ & $10.67^{\mathrm{a}}$ \\
\hline & Urea & $92.55^{\mathrm{a}}$ & $6.52^{\mathrm{c}}$ & $7.94^{\mathrm{b}}$ & 71.28 & $53.17^{\mathrm{b}}$ & $10.01^{\mathrm{b}}$ \\
\hline & Mix & $91.30^{\mathrm{b}}$ & $6.59^{\mathrm{b}}$ & $9.25^{\mathrm{a}}$ & 71.27 & $53.17^{\mathrm{b}}$ & $10.60^{\mathrm{a}}$ \\
\hline & Control & $91.20^{\mathrm{b}}$ & $5.43^{\mathrm{d}}$ & $7.23 b$ & 71.17 & $56.17^{\mathrm{a}}$ & $10.61^{\mathrm{a}}$ \\
\hline Mean & & 91.04 & 6.83 & 9.84 & 69.58 & 52.11 & 9.77 \\
\hline SEM & & 0.087 & 0.043 & 0.068 & 1.03 & 0.65 & 0.06 \\
\hline $\mathrm{CV}$ & & 0.33 & 0.096 & 0.27 & 1.45 & 1.55 & 2.43 \\
\hline SL & & $* * *$ & $* * *$ & $* * *$ & ns & $* *$ & *** \\
\hline
\end{tabular}

Note: HD: Harvesting date, FT: Fertilizer type DM: dry mater content, CP: crude protein, NDF: neutral detergent fiber, ADF: acid detergent fiber, ADL: acid detergent lignin, $\mathrm{p}^{* * *}$ : significant difference at p: $0.001, \mathrm{p}: * *$ at 0.05 
The higher CP content from the compost plots could be explained by the density of legume components in the pasture which was higher than other treatments including the nitrogen fertilizer. According to Bumane (2010) manure from large animals like cattle when applied to grazing pasture, helps to supply bio-available nitrogen and phosphorus. This increases vegetative parts of plants that in turn increases the nitrogen or crude protein portion of the pasture. Contradictory, nitrogen in chemical fertilizer fasten the growth of grass which was less in crude protein to compete and dominate over legumes. This finding was in agreement with several researchers in the past that crude protein content depends on plant species (Caddel and Allen 2010; Nemera 2016). The reason for suppression of legumes in the chemical fertilizer was this in part might be the roundabout role of nitrogen which induces the grass proportions that in turn suppress the legume proportions. Nitrogen application also affects legume development by its inhibitor role on Rhizobial nitrogen fixation. Hence, the large CP component from compost application was most probably brought about by higher composition of legumes and legumes generally have better content of $\mathrm{CP}$.

The CP content of the natural pasture has declined as age of harvesting increased. The decline in $\mathrm{CP}$ with plant maturity is in line with the report of Zewdu et al. (2010) in a study conducted on natural pasture. It might be due to dilution of $\mathrm{CP}$ by increasing the number of structural carbohydrates in the late harvesting forage or to the increasing dominance of grass over legumes, in proportion along the decreasing proportion of legumes in the grazing pasture which arises as a result of defoliation. This low legume proportion might be related to late harvesting was considered as one of the factors that reduce the crude protein content of pasture lands. The findings of Zewdu et al. (2010) showed a mean of CP content (10.87\%) which was higher than the result of present CP report $(9.84 \%$.

This might be caused by early harvesting (60 days) compared to our study (90 days). Moreover, the discrepancy of findings might be related to variations in soil structure, management practices, and weather conditions which were major factors influencing nutritional quality of grasses. Higher $\mathrm{CP}$ content contents in first harvest were highly related to early growing age of plants; young leaves, and flowers provide higher feed quality forage. In more mature plants, leaf ratio was less than stem ratio. So, nutritive value of this plant was lower in forage quality (Caddel and Allen 2010).

\section{Neutral detergent fiber}

The interaction of fertilizer type and harvesting age $(\mathrm{P}<0.001)$ wassignificantforNDF content. Age of harvest had significant effect $(\mathrm{P}<0.001)$ on NDF content unlike type of fertilizer application. At the same age of harvest, the effect of fertilizer application including zero fertilizer did not significantly affect the neutral detergent fiber content of natural pasture at $(\mathrm{P}>0.05)$.
At the same age of harvest, the effect of fertilizer application including zero fertilizer did not significantly affect the neutral detergent fiber content of natural pasture at $(\mathrm{P}>0.05)$. The results of the present study were in line with the findings of Nemera (2016) who described that the application of organic and inorganic fertilizer did not significantly affect $(\mathrm{P}>0.05)$ the NDF content of natural pasture in other parts of Ethiopia. However, Delevatti et al. (2019) stated that there was significant $(P<0.05)$ effect on fiber contents due to fertilizer effect. But age of harvesting had significant effect on NDF content $(\mathrm{P}<0.001)$. In the present study it was interconnected with age of harvest rather than treatments. In the current findings, NDF content of the forage samples increased in all treatments as age of harvest increases. As plants at matured age, plants become lignified and had highest neutral detergent fiber as indicated by Zewdu et al. (2010). Increased NDF content with advancing age of the natural pasture was also in line with Bilatu et al. (2013). The NDF obtained in the present study was lower $(71.17 \%)$ at 120 days than the results of Mahmut and Binali (2012), who reported that NDF for natural pasture was $(75.82 \%)$ at 170 days of harvesting. This is due to the fact that higher legume in the pasture has the advantage of providing higher protein than accumulating high NDF content. The differences in NDF also could be attributed to nature of the grass, soil, age of harvesting, and climatic conditions.

\section{Acid detergent fiber}

Harvesting age and application of fertilizer type significantly affected the acid detergent fiber at $(\mathrm{P}<0.05)$. The highest ADF was observed on unfertilized treatment at 120 days of harvesting age, the lowest was observed in all (compost, urea, and mix) treated treatments at (90 days) but treated were statistically similar with unfertilized treatment on the same harvesting age (90 days). At 120 days of harvest compost, nitrogen and combined treatments were statically the same.

The highest ADF was observed on unfertilized treatment at 120 days of harvesting age. The lowest ADF was observed in all (compost, urea, and mix) fertilized plots at (90 days) but treated were statistically similar with unfertilized tplot on the same harvesting age (90 days). Therefore, this study is in line with Hassan et al. (2015) Nemera (2016), in case of control treatment showed highest acid detergent fiber than treatments with fertilizer application. The results obtained also showed a linear increase in ADF content with a corresponding increase in harvesting date. The increased ADF contents with advanced age of harvesting might be associated with an increase in cell wall lignifications as forages get matured (McDonald et al. 2010). The current ADF $(52.11 \%)$ content is higher than the reports of Zewdu et al. (2010) which was $44.39 \%$. The reason might be due to early harvesting (60 days) compared to our study (90 days). 
Table 3. The correlation between forage yield, species composition, and chemical composition parameters

\begin{tabular}{|c|c|c|c|c|c|c|c|c|c|c|}
\hline & DMY & $\mathbf{G}$ & $\mathbf{L}$ & $\mathbf{F}$ & DM & Ash & $\mathbf{C P}$ & NDF & ADF & ADL \\
\hline DMY & 1 & $0.34^{\mathrm{ns}}$ & $-0.33^{\mathrm{ns}}$ & $-0.68^{\mathrm{ns}}$ & $0.74^{*}$ & $0.16^{\mathrm{ns}}$ & $-0.23^{\mathrm{ns}}$ & $0.47^{\mathrm{ns}}$ & $-0.003^{\mathrm{ns}}$ & $0.045^{\mathrm{ns}}$ \\
\hline G & & 1 & $-1.00^{* *}$ & $-0.054^{\mathrm{ns}}$ & $0.68^{\mathrm{ns}}$ & $-0.79^{*}$ & $-0.78^{*}$ & $0.43^{\mathrm{ns}}$ & $0.41^{\mathrm{ns}}$ & $-0.09^{\mathrm{ns}}$ \\
\hline $\mathrm{L}$ & & & 1 & $0.04^{\mathrm{ns}}$ & $-0.68^{\mathrm{ns}}$ & $0.789^{*}$ & $0.785^{*}$ & $-0.43^{\mathrm{ns}}$ & $-0.4^{\mathrm{ns}}$ & $0.09^{\mathrm{ns}}$ \\
\hline $\mathrm{F}$ & & & & 1 & $-0.52^{\mathrm{ns}}$ & $-0.2^{\mathrm{ns}}$ & $-0.1^{\mathrm{ns}}$ & $-0.5^{\mathrm{ns}}$ & $-0.2^{\mathrm{ns}}$ & $-0.4^{\mathrm{ns}}$ \\
\hline DM & & & & & 1 & $-0.4^{\mathrm{ns}}$ & $-0.6^{\mathrm{ns}}$ & $0.74^{*}$ & $0.5^{\mathrm{ns}}$ & $0.26^{\mathrm{ns}}$ \\
\hline Ash & & & & & & 1 & $0.76^{*}$ & $-0.4^{\mathrm{ns}}$ & $-0.6^{\mathrm{ns}}$ & $-0.17^{\mathrm{ns}}$ \\
\hline $\mathrm{CP}$ & & & & & & & 1 & $-0.7^{\mathrm{ns}}$ & $-0.6^{\mathrm{ns}}$ & $-0.2^{\mathrm{ns}}$ \\
\hline NDF & & & & & & & & 1 & $0.85^{* *}$ & $0.75^{*}$ \\
\hline $\mathrm{ADF}$ & & & & & & & & & 1 & $0.77^{*}$ \\
\hline $\mathrm{ADL}$ & & & & & & & & & & 1 \\
\hline
\end{tabular}

Note: ***: P < 0.001; *: P < 0.05; **: P< 0.01; NS : Non Significant, G: Grass, L : Legumes, F : forbs, DMY: Dray matter yield; DM: dry mater content; CP: Crude protein; NDF: Neutral detergent fiber; ADF: Acid detergent fiber; ADL: Acid detergent lignin

\section{Acid detergent lignin}

The acid detergent lignin (ADL) of natural pasture was high significantly affected by fertilizer application and stage of harvesting at $(\mathrm{P}<0.001)$. The highest ADL contents were observed from compost followed by $\mathrm{mix}$ and unfertilized treatment at 120 days of harvesting but, $\mathrm{N}$ fertilizer decreases the ADL content at 90 days of harvesting. The lowest ADL (10.01\%) also observed on $\mathrm{N}$ fertilizer than compost, mix, and unfertilized treatment at 120 days of harvesting.

The lowest ADL (10.01\%) also observed on $\mathrm{N}$ fertilizer than compost, mix, and unfertilized treatment at 120 days of harvesting, these results coincide with the findings of Cahit et al. (2010). This was because the urea fertilizer promotes the growth of new leaves and shoots resulting in low lignin, which compensates for the increase in lignin content of other tissues. Generally, the ADL content increases with increase in plant maturity under all fertilizer type indicating that an increment in the lignin at later harvest ages could be due to an increase indigestible fiber (more stem) and decrease in nutrient content (less leaf fraction) (Feyissa et al. 2014).

Similarly, Bilatu et al. (2013) reported that that lignin content increased as days of harvesting became longer but decreased as $\mathrm{N}$ fertilizer increased. Regarding ADL content, an increase in concentration along with increment of harvesting age was reported by Tolcha (2017).

\section{Correlation analysis}

The relationships among forage yield, species composition, and chemical composition parameters of natural pasture are shown in Table 3.

The DMY was significantly moderate positive $(\mathrm{P}<0.05)$ correlation with DM content while there was no significant correlation with other parameters. Grass was significant perfect negative $(\mathrm{P}<0.01)$ correlation with legumes and significant negative $(\mathrm{P}<0.05)$ strong correlation with ash and CP. In the current finding the correlation between the proportions of grasses and legumes was perfect negative with a value of -1.000 , reflecting the existence of competition between the two species during (Nemera et al. 2017). Legumes were significant strong positive $(P<0.05)$ correlation with ash and CP. DM was significant moderate positive $(\mathrm{P}<0.05)$ correlation with NDF. Ash was significant moderate positive $(\mathrm{P}<0.05)$ correlation with $\mathrm{CP}$. NDF was significantly strong positive $(\mathrm{P}<0.01)$ and $(\mathrm{P}<0.05)$ correlation with $\mathrm{ADF}$, ADL respectively and ADF was significantly strong positive $(\mathrm{P}<0.05)$ correlation with ADL.

In conclusion, the study revealed that application of inorganic, mixed fertilizer, and compost in the order of priority could be used as natural pasture improvement strategies in the highlands of Ethiopia. By doing so, it is possible to increase species composition, yield and chemical composition of natural pasture and thereby enhance livestock productivity in the area. In terms of stage of harvest harvesting at 120 days was better than earlier harvesting date (90 days) as it enabled to obtain optimum dry matter yield and moderate nutritive value. However, this research needs to be repeated over years and or locations to come with reliable data in further natural grazing land management improvement systems in the highlands.

\section{REFERENCES}

Abadi N. 2017. Pasture management and improvement strategies in Ethiopia. J Biol Agric Healthcare 7 (1): 69-78

Agza B, Kassa B, Zewdu S, Aklilu E. 2013. Forage yield and nutritive value of natural pastures at varying levels of maturity in North West Lowlands of Ethiopia. World J Agric Sci 1 (3): 106-112.

Ahmed M, Yossif I. 2013. Effect of organic and inorganic fertilizers on proximate analysis of Rhodes grass (Chloris gayana L. Knuth.). Universal J Plant Sci 1 (4): 137-140.

Angassa A. 2014. Effects of grazing intensity and bush encroachment on herbaceous specie and rangeland conditions in southern Ethiopia. Land Degrad Dev 25: 438-451.

AOAC. 2004. Official Methods of Analysis. (16th Ed.) Association of Official Analytical Chemists, Washington DC.

Aregheore EM. 2002. Voluntary intake and digestibility of fresh, wilted and dry Leucaena (Leucaena leucocephala) at four levels to a basal diet of guinea grass (Panicum maximum). Asian-Aust J Anim Sci 15: 1139-1146.

Atsbha T, Estifanos A, Wayu S, Tesfay T, Baraki A. 2015. Rehabilitation of degraded pasture land through application of urea and slurry: The ase of Ayba pasture land, Southern Tigray, Ethiopia. Livestock Res Rural Dev 27 (9), 201.

Bilatu A, Binyam K, Solomon Z, Eskinder A, Ferede A. 2013. Forage yield and nutritive value of natural pastures at varying levels of maturity in northwest lowlands of Ethiopia. World J Agric Sci 1 (3): 106-112. 
Bumane S. 2010. The influence of NPK fertilization on Lolium perennial L. forage quality. Agron Res 8, 531-536.

Caddel J, Allen E. 2010. Forage quality interpretations. http://virtual.chapingo.mx/dona/paginaCBasicos/f-2117.pdf

Cahit B, Sebahattin A, Osman Y. 2010. Effects of nitrogen, phosphorus and potassium fertilization on the quality and yield of native rangeland. Turk J Field Crops 15 (2): 164-168.

CSA [Central Statistics Agency]. 2018.Agricultural Sample Survey. Report on livestock and livestock characteristics (Private peasant holdings). Volume 2 Statistical Bulletin: 587. 100p.

CSA [Central Statistics Agency]. 2017. Agricultural sampling survey report on livestock and livestock characteristics (private peasant holdings). Statistical Bull 583, Addis Ababa, Ethiopia

David Ma, Angello M, George M, Liliane P, Kelvin M. 2019. Forage growth, yield and nutritional characteristics of four varieties of Napier grass (Pennisetum purpureum Schumach) in the west Usambara Highlands, Tanzania. Sci Afr 6: 1-9.

Delevatti LM, Cardoso AS, Barbero RP, Leite RG, Romanzini EP, Ruggieri AC, Reis RA. 2019. Effect of nitrogen application rate on yield, forage quality, and animal performance in a tropical pasture. Sci Rep 9 (1): 1-9.

Denekew Y, Tamir B, Melaku S. 2005. Effect of harvesting date on composition and yield of natural pasture in North-Western Ethiopia. Trop Sci 45: 19-22

Feyissa F, Shivprasad, Assefa G, Bediye S, Kifaw G, Kehaliew A, Kebede G. 2014. Dynamics in nutritional characteristics of natural pasture hay as affected by harvesting stage, storage method and storage duration in the cooler tropical high lands. Afr J Agric Res 9 (43): 3233-3244.

Feyter C, O’Connor MB, Addison B. 2005. Effects of rates and times of nitrogen application on the production and composition of dairy pastures in Waikato district, New Zealand. NZ J Exp Agric 13: 247 52.

Głowacz K, Niżnikowski R. 2018. The effect of animal grazing on vegetation and soil and element cycling in nature. Environ Sci Pollut Res Intl 25 (4): 3565-3570. https://doi.org/10.1007/s11356-017-0740 5

Gomide JA, Noller CH, Mott GO, Conard JH, Hill DL. 1969. Effect of plant age and nitrogen fertilization at ion on the chemical composition and invitro-cellulose digestibility of tropical grasses. Argon J 16: 116-120.

Halgerson JL, Sheaffer CC, Martin NP, Peterson PR, Weston SJ. 2004. Near-infrared reflectance spectroscopy prediction of leaf and mineral concentrations in alfalfa. Agron J 96, 344-351.

Hanife M, Ayan Z, Ugur B, Ozlem A. 2010. The effects of different improvement methods on pasture yield and quality of hay obtained from the abandoned rangeland. Tur J Field Crops 15 (2): 198-203.

Hassan A, Zewdu T, Urge M, Fikru S. 2015. Effects of nitrogen fertilizer application on nutritive value of Cenchrus ciliaris and Panicum maximum grown under irrigation at Gode, Somali region. Global $\mathbf{J}$ Med Res: L Nutr Food Sci 15 (1): 1-9.

Kebede G, Assefa G, Feyissa F, Mengistu A. 2016. A review on some management and improvement practices of natural pasture in the mid and high-altitude areas of Ethiopia. Int J Livest Res 6 (5): 1-14. DOI: $10.5455 /$ ijlr.20160406103816.

Ketema M, Siegfried B. 2011. Determinants of manure and fertilizer applications in eastern highlands of Ethiopia. Q J Intl Agric 50 (3) 237-252.

Mahmut DAŞC, Binali Ç. 2012. effects of fertilization on forage yield and quality in range sites with different topographic structure. Turk J Field Crops 16 (1): 15-22.

Malede Birhan and Takele Adugna, 2014. Livestock Feed Resources Assessment, Constraints and Improvement Strategies in Ethiopia. Middle-East J Sci Res 21 (4): 616-622.

Mannetje T, Jones J, Stobbs H. 1976. Pasture evaluation by grazing experiments. In: Shaw NH, Bryan WW (eds) Tropical Pasture Research. Principles \& Methods. Bull. 51. Commonwealth Agricultural Bureaux, Farnham Royal, Bucks, England.

Marie S, Pavlina M, Karel F, Hana K, Oldrich L, Jan P. 2014. Effect of organic fertilizers on botanical composition of grassland, herbage yield and quality. Agriculture 60 (3): 87-97. DOI: 10.2478/agri-20140010 .

McDonald P, Edwards RA, Greenhalgh JFD, Morgan CA, Sinclair LA, Wilkinson RG. 2010. Animal Nutrition. $7^{\text {th }}$ ed. Prentice-Hall, Harlow, England, London.

Maynard AL, Losli KJ, Hintz FH. 1981. Animal Nutrition, 7th ed. Tata Mc Graw Hill Publishing Company Limited, New Delhi, India.
MDOA [Mecha District Office of Agriculture]. 2015. Baseline Linereport. Mecha, District of Development of Agricultural Office, Ethiopia.

Mekuria W, Wondie M, Amare T, Wubet A, Feyisa T, Yitaferu B. 2018. Restoration of degraded landscapes for ecosystem services in NorthWestern Ethiopia. Heliyon 4 (8), e00764. DOI: 10.1016/j.heliyon.2018.e00764

Melese A, Markku Y. 2016. Effects of applications of lime, wood ash, manure and mineral $\mathrm{P}$ fertilizer on the inorganic $\mathrm{P}$ fractions and other selected soil chemical properties on acid soil of Farta District, Northwestern highland of Ethiopia. Afr J Agric Res 11 (2): 87-99.

Mengistu A, Kebede G, Feyissa F, Assefa G. 2017. Review on major feed resources in Ethiopia: Conditions, challenges and opportunities. Acad Res J Agric Sci Res 5 (3): 176-185.

Mirzaei F. 2012. Minerals profile of forages for grazing ruminants in Pakistan. J Anim Sci 2. 133-141

Lloyd M, Ritchey E. 2014. Lime and nutrition recommendations, Cooperative Extension Service, University of Kentucky College of Agriculture, Food and Environment, Lexington, Ky, 40546.

Nega I, Seyoum M, Berhanu MN. 2015. A study of forage yield and nutritive value of natural pastures at varying levels of maturity in North West Lowlands of Ethiopia. Front Agric Food Technol 3 (1): 259-264.

Nemera F. 2016. Assessment of Vegetation Dynamics as Feed Resource and Improvement of Grazing Lands in Sheep Dominated Areas of West Shoa Zone, Oromia Region, Ethiopia. [Dissertation]. Haramaya University.

Nemera F, Zewdu T, Ebro A. 2018. Effect of organic and inorganic fertilizers applications on the highlands grasslands of the acidic soil physical and chemical properties: The case of Meta-Robi district. J Biol Agric Healthcare 18 (3): 15-22

Nemera F, Tessema ZK, Ebro A. 2017. Effect of organic and inorganic fertilizer application on improvement of degraded grazing land in the central highland of Ethiopia. Livestock Res Rural Dev 29 (3). http://www.lrrd.org/lrrd29/3/tess29059.html

Numan K, Mustafa A, Hatice H, Rüștü H, Tugay A. 2018. Botanical composition and in situ dry matter degradability of legume- grass mixture pasture fertilized with different amounts of nitrogen. Turk $\mathbf{J}$ Agric Food Sci Technol 6 (1): 16-21.

Rambau MD, Fushai F, Baloyi JJ. 2016. Productivity, chemical composition and ruminal degradability of irrigated Napier grass leaves harvested at three stages of maturity. South Afr J Anim Sci 46 (4): 398-408.

Stephen K, Barnhart AP, Mallarino J, Sawyer E. 2013. Extension and outreach prepared for Iowa State University.

Tegegne A, Gebremedhin B, Dirk H. 2013. Smallholder dairy production and marketing systems in Ethiopia: IPMS experiences and opportunities for market-oriented development. IPMS Working Paper 31. ILRI, Nairobi, Kenya.

Tesfay A, Awet E, Temesgen T, Solomon W, Adhanom B. 2017. Improving the productivity of degraded pasture land through legume forages over sowing. Intl J Sci Technol Soc 5 (3): 33-36.

Tolcha T. 2017. Effect of nitrogen fertilizer and harvesting days on yield and quality of Rhodes Grass (Chloris gayana) Under Irrigation at Gewane, North-Eastern, Ethiopia. [Thesis]. Haromaya University, Ethiopia.

Tothill J, Jone M, Hargreaves N. 1978. BOTANAZ: A Field and computing package for assessment of plant biomass and botanical composition, Ecology and Management of World Savannas. Australian Academy of Science, Canberra, Australia

Ulfina G, Habtamu A, Jiregna D, Chala M. 2013. Utilization of brewer's waste as replacement for maize in the ration of calves. Res Web Pub 1 (1): 8-11.

Van Soest PJ, Robertson HB, Lewis BA. 1991. Method of dietary fiber and non-starch polysaccharides in relation to animal material. J Dairy Sci 74: 3583-3587.

Yadessa E, Ebro A, Fita L, Asefa G. 2016. Livestock feed production and feed balance in Meta Robi District, West Shewa Zone, and Oromo Regional State, Ethiopia. Acad Res J Agric Sci Res 4 (2): 45-54.

Zewdu T, Abate A, Melaku S. 2010. Botanical composition, yield and nutritional quality of grassland in relation to stages of harvesting and fertilizer application in the highlands of Ethiopia. Afr J Range Forage Sci 27 (3): 117-124. 